удк 65.012.123

$@ \bowtie$ Correspondence author

T. P. Kovalenko

kovalenkotaniy@gmail.com

Т. П. Коваленко, С. С. Лис, В. О. Сердюк, І. Р. Галянчук, Н. М. Лашковська

Національний університет "Львівська політехніка", м. Львів, Україна

\title{
АНАЛІЗ ЕФЕКТИВНОСТІ РОБОТИ МОДЕРНІЗОВАНОЇ ВОДОПІДГОТОВЧОЇ УСТАНОВКИ КОТЕЛЬНІ ПІДПРИЄМСТВА
}

\begin{abstract}
Об'єктом дослідження є котельня підприємства ТзОВ "Гофрон", розташована в с. Малехів Жовківського району, призначена для забезпечення технологічних потреб підприємства в парі, а також забезпечення потреб тепла на опалення виробничого корпусу. На підприємстві приготування живильної води для котлів фірми Ferroli виду Vapoprex HVP 800 здійснено за допомогою водопідготовчої установки (ВПУ) SF-10A. Установка серії SF-10A складається з двох натрій-катіонітних фільтрів із загальним блоком управління і солерозчинним баком для приготування сольового розчину. Як фільтрувальний матеріал в установці SF-10A використано катіонообмінні смоли, що мають високу місткість за солями жорсткості. Наведено реакції, які описують процес іонного обміну за схемою двоступеневого натрій-катіонування, а також переваги цього методу. Проведено лабораторні дослідження з вивчення впливу ВПУ SF-10А на якість води. Встановлено, що після ВПУ жорсткість води зменшилась до 0,01 мг-екв/л. Наведено декілька етапів процесу регенерації двоступеневої натрій-катіонітової установки. Проведено розрахунок питомої витрати солі $\mathrm{NaCl}$ (а) на одну регенерацію та встановлено, що на фільтри I ступеня $a=$ 135 г/г-екв, для II ступеня $a=350$ г/г-екв. Проаналізовано ефективність роботи ВПУ SF-10A та розраховано техніко-економічні показники котельні підприємства ТзОВ "Гофрон" після модернізації ВПУ. Визнасено, що ККД до модернізації ВПУ підприємства становило $82 \%$, а після модернізації - $91 \%$.
\end{abstract}

Ключові слова: вода; котельня; підприємство; водопідготовча установка; іонообмінний метод; пом'якшення води.

Вступ. На сьогодні водопідготовка і водоочищення для різних виробничих процесів стає дедалі актуальнішою для багатьох підприємств різних галузей промисловості. Це передусім пов'язано з тим, що теплові установки на них вичерпали свій ресурс і не відповідають сучасним експлуатаційним нормам і нормам енергоефективності. Цей факт головно проявляється в падінні або нестабільності температурних рівнів, а також у неможливості зношеного котельного устатковання забезпечувати розрахункові температурні режими за встановлених норм споживання палива. Відповідно перевитрата енергоносія веде до збільшення витрат підприємства, підвищення вартості його продукції і як наслідок - зниження конкурентоспроможності підприємства на ринку (Mysak, Tymofieiev \& Zaiats, 2009).

Водопідготовка у промисловості - одне з найважливіших завдань в організації виробництва, оскільки вода $\epsilon$ невід'ємною частиною багатьох виробничих процесів. Вихідна вода містить велику кількість домішок. Вико- ристання неочищеної води призводить не тільки до утворення у трубах накипу і корозії, а й до зносу устаткування, підвищення енерговитрат теплової мережі. Тому проблема створення ефективної, недорогої технології оброблення води є досить актуальною.

Одним із показників якості води, що регламентується нормативними документами під час використання для господарських або технічних потреб різних видів промисловості, є показник загальної жорсткості води (Manivasakam, 2011). Для доведення його до відповідних норм, залежно від якості вихідної води, застосовують реагентний, термічний, мембранний, іонообмінний методи пом'якшення, а також різні їх комбінації (Mysak, Tymofieiev \& Zaiats, 2009; Manivasakam, 2011; Zapolskyi, 2005; Fedoseev, 2005).

На сьогодні, як у теплоенергетиці, так і в інших галузях національного господарства для пом'якшення вихідних вод найширше застосовують метод іонного обміну. Пом'якшення води методом іонного обміну (очи-

Інформація про авторів:

Коваленко Тетяна Павлівна, канд. хім. наук, доцент, кафедра теплоенергетики, теплових і атомних електричних станцій. Email: kovalenkotaniy@gmail.com; https://orcid.org/0000-0002-6866-5979

Лис Степан Степанович, канд. техн. наук, ст. викладач, кафедра теплоенергетики, теплових і атомних електричних станцій. Email: lysss@ukr.net; https://orcid.org/0000-0002-7359-1177

Сердюк Віталій Олександрович, канд. хім. наук, науковий співробітник, кафедра органічної xiмiї. Email: serdjuklvov@gmail.com; https://orcid.org/0000-0002-8303-4331

Галянчук Ігор Романович, ст. викладач, кафедра теплоенергетики, теплових і атомних електричних станцій. Email: i_galyanchuk@yahoo.com; https://orcid.org/0000-0001-6242-1749

Лашковська Надія Михайлівна, ст. викладач, кафедра теплоенергетики, теплових і атомних електричних станцій. Email: nadiya.lashkovska@gmail.com

Цитування за ДСту: Коваленко Т. П., Лис С. С., Сердюк В. О., Галянчук І. Р., Лашковська Н. М. Аналіз ефективності роботи модернізованої водопідготовчої установки котельні підприємства. Науковий вісник НЛтУ України. 2019 , т. 29 , № 6. С. 87-91.

Citation APA: Kovalenko, T. P. , Lys, S. S. , Serdiuk, V. O. , Galyanchuk, I. R. , \& Lashkovska, N. M. (2019). The analysis of the efficiency of modernized water treatment equipment of enterprise boiler house. Scientific Bulletin of UNFU, 29(6), 87-91. https://doi.org/10.15421/40290618 
щення від солей жорсткості) - процес, унаслідок якого катіони магнію і кальцію, проходячи через фільтр, замінюються на іони натрію або водню. У ролі фільтра використовується іонообмінна смола, на поверхні якої і відбувається ця реакція. Після вироблення ресурсу смола потребує регенерації - в автоматичному режимі через пом'якшувач пропускається розчин солі. Іонообмінні фільтри для очищення води цим самим відновлюють свої властивості, і знову стають придатними до використання. Періодичність процесу розраховують виходячи 3 даних за обсягом іонообмінної смоли і якості води (Barochkin et al., 2005).

Отже, проблема часткового чи повного вилучення іонів магнію і кальцію в процесі водопідготовки на цей момент вирішена неповністю. Хоча розроблено і використовують на практиці велику кількість технологій і конструкцій водопом'якшувальних установок, усі вони мають низку недоліків - або металомісткі та дорогі у будівництві, або ненадійні в роботі та складні в експлуатації. Недостатня ефективність роботи споруд, що застосовують для очищення води, зумовлює необхідність пошуку інших рішень.

Об'єкти та методи дослідження. Об'єкти досліджень. Котельня підприємства ТзОВ "Гофрон", розташована по вул. Лесі Українки № 70 у с. Малехів Жовківського р-ну, призначена для забезпечення технологічних потреб підприємства в парі, а також забезпечення потреб тепла на опалення виробничого корпусу. Приготування живильної води для котлів фірми Ferroli виду Vapoprex HVP 800 (табл. 1) здійснюється за допомогою водопідготовчої установки (ВПУ).
Табл. 1. Основні технічні характеристики котла Vapoprex HVP 800

\begin{tabular}{|c|c|c|c|}
\hline $\begin{array}{c}\text { № } \\
\text { 3/п }\end{array}$ & Назва показника & Розмірність & Значення \\
\hline 1 & Паропродуктивність & кг/год & 800 \\
\hline 2 & Теплова потужність & ккал/год & 473880 \\
\hline 3 & Аеродинамічний опір котла & мбар & 4,6 \\
\hline 4 & Тиск пари & МПа & 1,2 \\
\hline 5 & Температура пари & ${ }^{\circ} \mathrm{C}$ & 187 \\
\hline 6 & Температура живильної води & ${ }^{\circ} \mathrm{C}$ & 60 \\
\hline 7 & Температура відхідних газів & ${ }^{\circ} \mathrm{C}$ & 160 \\
\hline 8 & Об'єм води в котлі & літр & 1280 \\
\hline 9 & $\begin{array}{c}\text { Витрата палива (природного га- } \\
\left.\text { зу при } Q_{H}^{p}=8050 \text { ккал/нм }{ }^{3}\right)\end{array}$ & нм $^{3} /$ год & 63,4 \\
\hline 10 & ККД & $\%$ & 91 \\
\hline 11 & Маса котла & кг & 2700 \\
\hline
\end{tabular}

Для деаерації води, яка подається на котел, і підживлення водогрійної частини котельні на трубопроводі живильної води парового котла Vapoprex HVP 800 встановлено установку хімічної деаерації типу ES6 Grünbeck (табл. 2).

Табл. 2. Технічна характеристика установки хімічної деаерації ES6 Grünbeck

\begin{tabular}{|c|c|c|c|}
\hline $\begin{array}{c}\text { № } \\
\text { 3/п }\end{array}$ & Назва показника & Розмірність & Значення \\
\hline 1 & Продуктивність & л/год & $30-6000$ \\
\hline 2 & Номінальний тиск & бар & 10 \\
\hline 3 & Об'єм баку & л & 60 \\
\hline 4 & Електрична потужність & ВА & 10 \\
\hline 5 & Маса & кг & 6,3 \\
\hline
\end{tabular}

На підприємстві ТзОВ "Гофрон" використовують воду з наявної мережі внутрішнього водопроводу низької якості (табл. 3).

\begin{tabular}{|c|c|c|c|c|}
\hline \multirow{2}{*}{ Показник } & \multirow{2}{*}{$\begin{array}{c}\text { Одиниця } \\
\text { вимірювання }\end{array}$} & \multicolumn{3}{|c|}{ Якість води } \\
\hline & & Вимоги* & Водопровідна вода & Пом'якшена вода після ВПУ \\
\hline$\overline{\mathrm{pH}}$ & од. $\mathrm{pH}$ & $6,0-9,0$ & $\overline{7,4}$ & 8,2 \\
\hline Каламутність & мГ/л & $<2,6$ & 40,5 & 0,85 \\
\hline Кольоровість & градуси & не більше 30 & 60 & 25 \\
\hline Запах & бали & Відсутній & 2 & Відсутній \\
\hline Загальний вміст заліза & МГ/Л & не більше 0,3 & 5,0 & 0,15 \\
\hline Загальна жорсткість & мГ-екв/Л & до 0,02 & 8,2 & 0,01 \\
\hline Загальна лужність & мГ-екв/л & не нормується & 7,6 & 7,4 \\
\hline Окислюваність & $\mathrm{M \Gamma O}_{2} / \pi$ & не більше 0,6 & 2,88 & 0,45 \\
\hline Сухий залишок & МГ/л & до 1000 & 454 & 454 \\
\hline
\end{tabular}

Примітка: * - взято 3 (RD 24.032.01-91, 1991)

Методи дослідження. Для отримання наукових i практичних результатів використано фізико-хімічні методи аналізу якості води та іонообмінний метод ії очищення (Kucheryk, Omelchuk \& Homelia, 2010, 2012). Для оцінки експериментальних результатів застосовано математичні методи опрацювання даних, методи планового експерименту й засобів математичної статистики.

Мета дослідження полягає у визначенні впливу модернізованої водопідготовчої установки на енергоефективність роботи котельні підприємства ТзОВ "Гофрон".

Для досягнення поставленої мети необхідно вирішити такі завдання:

• виконати фізико-хімічний аналіз вихідної води та води після стадії очищення;

- розробити заходи із вдосконалення водопідготовчої установки на виробництві;

- експериментально визначити параметри процесу повторного використання відпрацьованих розчинів $\mathrm{NaCl}$; встановити вплив його використання на тривалість пом'якшення води;

- провести економічну оцінку запропонованої водопідготовчої установки.
Результати дослідження та обговорення отриманих результатів. Отримання якісного теплоносія, надійна робота устаткування та трубопроводів залежить насамперед від ефективності системи водопідготовки.

До проведення модернізації ВПУ котельні підприємства ТзОВ "Гофрон", використовували класичну схему водопідготовки, яка включала пом'якшення води і заснована на традиційних фільтрах оброблення води вітчизняного виробництва з ручним керуванням. Механічна фільтрація і часткове знезалізнення води в них здійснювалися на піску, а для пом'якшення води в них часто застосовувався сульфовуголь.

Під час експлуатації цієї схеми були такі недоліки:

- високий відсоток продувки котлів (до $15 \%$ );

- зношення наявного устатковання;

- значні витрати реагентів (вапно, кухонна сіль);

- утворення великого обсягу вапняних шламів і засолених стоків;

- ручне управління технологічними процесами.

Отже, на основі аналізу роботи діючої водопідготовчої установки, було зроблено висновок про необхід- 
ність її вдосконалення шляхом встановлення нової установки пом'якшення води 3 високоефективними сучасними завантаженнями й автоматичною регенерацією.

У табл. 3 наведено показники якості водопровідної та пом'якшеної води після ВПУ. 3 огляду на індивіду- альні особливості підприємства, хімічний аналіз води і техніко-економічні міркування було підібрано ВПУ SF10A (RD 10-179-98, 1998) (табл. 4).

Табл. 4. Технічна характеристика установки SF-10A

\begin{tabular}{|c|c|c|}
\hline Показник & Одиниці вимірювання & Значення \\
\hline Робочий тиск & атм & $2,5-6,0$ \\
\hline Напруга електричної мережі & В & 220, сила струму до 6 А \\
\hline Температура повітря в приміщенні & ${ }^{\circ} \mathrm{C}$ & $+5-+35$ \\
\hline Вологість & $\%$ & не більше 70 \\
\hline Продуктивність & $\mathrm{m}^{3} /$ год & $1,0-1,5$ \\
\hline Розміри фільтра (Н/D) & мм & $1120 / 254 \times 2+$ сольовий бак 100 л \\
\hline Приєднувальні розміри Ду, вхід/вихід/дренаж & мм & $25 / 25 / 15$ \\
\hline
\end{tabular}

ВПУ SF-10А виконана за схемою двоступеневого натрій-катіонування - це один 3 найпопулярніших способів пом'якшення води на більшості підприємств. Він базується на властивості іонообмінних матеріалів змінювати іони різних елементів, що не залишають накип на нагрітих поверхнях (теплообмінниках, жаротрубних котлах, важких екранах опалювального устатковання), на іони магнію і кальцію. Сам процес описується такими реакціями (Mysak, Tymofieiev \& Zaiats, 2009; Zapolskyi, 2005):

$$
\begin{gathered}
2 \mathrm{Na}[\mathrm{K}]+\mathrm{Ca}\left(\mathrm{HCO}_{3}\right)_{2} \rightarrow \mathrm{Ca}[\mathrm{K}]_{2}+2 \mathrm{NaHCO}_{3}, \\
2 \mathrm{Na}[\mathrm{K}]+\mathrm{Mg}\left(\mathrm{HCO}_{3}\right)_{2} \rightarrow \mathrm{Mg}[\mathrm{K}]_{2}+2 \mathrm{NaHCO}_{3}, \\
2 \mathrm{Na}[\mathrm{K}]+\mathrm{CaCl}_{2} \rightarrow \mathrm{Ca}[\mathrm{K}]_{2}+2 \mathrm{NaCl}, \\
2 \mathrm{Na}[\mathrm{K}]+\mathrm{MgCl}_{2} \rightarrow \mathrm{Mg}[\mathrm{K}]_{2}+2 \mathrm{NaCl}_{2}, \\
2 \mathrm{Na}[\mathrm{K}]+\mathrm{CaSO}_{4} \rightarrow \mathrm{Ca}[\mathrm{K}]_{2}+\mathrm{Na}_{2} \mathrm{SO}_{4}, \\
2 \mathrm{Na}[\mathrm{K}]+\mathrm{MgSO}_{4} \rightarrow \mathrm{Mg}[\mathrm{K}]_{2}+\mathrm{Na}_{2} \mathrm{SO}_{4}, \\
2 \mathrm{Na}[\mathrm{K}]+\mathrm{CaSiO}_{3} \rightarrow \mathrm{Ca}[\mathrm{K}]_{2}+\mathrm{Na}_{2} \mathrm{SiO}_{3}, \\
2 \mathrm{Na}[\mathrm{K}]+\mathrm{MgSiO}_{3} \rightarrow \mathrm{Mg}[\mathrm{K}]_{2}+\mathrm{Na}_{2} \mathrm{SiO}_{3},
\end{gathered}
$$

де $[\mathrm{K}]$ - не розчинна матриця катіоніта.

Установка безперервної дії SF-10A призначена для пом'якшення води на об'єктах 3 24-годинним циклом виробництва, а також там, де перерва в подачі пом'якшеної води не допускається за умовами експлуатації і вимогами технологічних регламентів. Установка серії SF-10A складається 3 двох натрій-катіонітних фільтрів iз загальним блоком управління і солерозчинним баком для приготування сольового розчину. У будь-який момент часу один 3 двох катіонітних фільтрів установки знаходиться в режимі пом'якшення води, інший - у режимі регенерації або очікування.

Як фільтрувальний матеріал в установці SF-10A використовували катіонообмінні смоли, що мають високу місткість за солями жорсткості. Періодичну регенерацію смоли (відновлення ii ємності) здійснювали шляхом пропуску розчину хлориду натрію $(\mathrm{NaCl})$ через смолу. У процесі регенерації відбуваються такі реакції:

$$
\mathrm{Ca}[\mathrm{K}]_{2}+2 \mathrm{NaCl} \rightarrow 2 \mathrm{Na}[\mathrm{K}]+\mathrm{CaCl}_{2} \text {, }
$$$$
\mathrm{Mg}[\mathrm{K}]_{2}+2 \mathrm{NaCl} \rightarrow 2 \mathrm{Na}[\mathrm{K}]+\mathrm{MgCl}_{2}
$$

$\mathrm{NaCl}$ застосовували для регенерації завдяки їі доступності, а також внаслідок утворення добре розчинних солей $\mathrm{CaCl}_{2}$ i $\mathrm{MgCl}_{2}$, які легко видаляються 3 регенераційним розчином і відмивною водою.

Під час регенерації виконували такі операції:

1. Розпушували катіоніт водопровідною водою, що має на меті розпушити ущільнені шари катіоніту і видалити принесені зважені речовини. Тривалість розпушування становить приблизно 20-30 хв;

2. Регенерували 5-8 \% розчином солі - процес відновлення заміщених іонів $\mathrm{Na}^{+}$на іони $\mathrm{Ca}^{2+} \mathrm{i} \mathrm{Mg}^{2+}$. Час пропуску регенераційного розчину залежить від робочої місткості фільтра, концентрації сольового розчину, необ- хідного ступеня пом'якшення і змінюється від 25 до 40 хв;

3. Відмивали катіоніт від продуктів регенерації водопровідною водою. Питомі витрати відмивної води 5-6 м на $1 \mathrm{~m}^{3}$ катіоніту. Відмивання закінчується в разі зниження жорсткості відмитої води до 0,1 ммоль/дм ${ }^{3}$.

У цій роботі вважали доцільним експериментально визначити мінімально допустиму концентрацію $\mathrm{NaCl}$ у відпрацьованому розчині і співвідношення часу подачі відпрацьованого і свіжого розчинів, за яких тривалість пом'якшення води не зменшується. Результати експериментальних досліджень показано на рисунку.

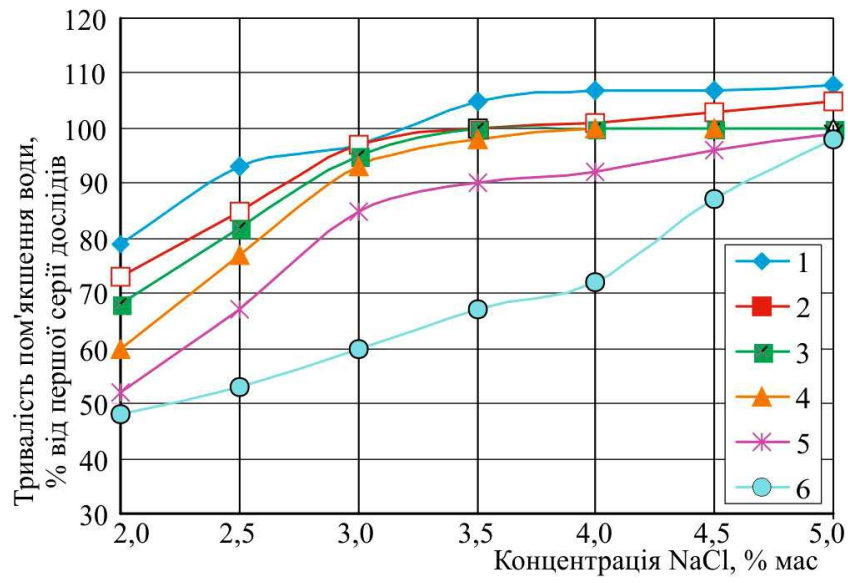

Рисунок. Вплив використання відпрацьованого регенераційного розчину на тривалість пом'якшення води за різних співвідношень часу подачі відпрацьованого і свіжого розчинів у відсотках від часу регенерації: 1) 30/70; 2) 35/65; 3) 40/60; 4) 50/50; 5) $55 / 45$; 6) $60 / 40$

Як видно з рисунка, тривалість пом'якшення води не зменшується, якщо концентрація відпрацьованого регенераційного розчину (ВРP) не нижча 3,5 \% і час подачі відпрацьованого розчину становить не більше $50 \%$ від загальної тривалості регенерації.

Отже, для фільтрів першого ступеня відбір ВРР на повторне використання починали після досягнення максимальних концентрацій солей жорсткості, при цьому середня концентрація $\mathrm{NaCl}$ в ВРР повинна бути не нижче $3,5 \%$. Щодо фільтрів другого ступеня, то тут було вирішено починати відбір ВРР на повторне використання у момент досягнення концентрації $\mathrm{NaCl}$ не нижче 3,5\% і продовжувати відбір до моменту падіння концентрації нижче 3,5 \%, тому що жорсткість ВРР після фільтрів другого ступеня низька і значення параметра $D$ (відношення середньої концентрації солі в еквівалентній формі до середньої жорсткості відпрацьованого регенераційного розчину) завжди високе. 
Витрату солі $\mathrm{NaCl}\left(p_{\mathrm{NaCl}}\right)$ на одну регенерацію розраховували за такою формулою:

$$
p_{\mathrm{NaCl}}=S \cdot a \cdot h_{k} \cdot e_{\mathrm{pNa}} / 1000, \mathrm{\kappa г,}
$$

де: $S$ - площа фільтра, м²; $h_{k}$ - висота шару катіоніту, м; $e_{\mathrm{pNa}}-$ робоча обмінна ємність катіонітового фільтра в разі натрій-катіонування, г-екв/ $\mathrm{M}^{3} ; a-$ питома витрата солі на 1 г-екв робочої обмінної ємності катіоніту, г/гекв.

За результатами розрахунку, питома витрата солі $\mathrm{NaCl}$ для двоступеневої натрій-катіонітної установки SF-10A становить: на фільтри I ступеня $a=135$ г/г-екв, для II ступеня $a=350$ г/г-екв. Технологічні показники Na-катіонітних фільтрів наведено в табл. 5.

Табл. 5. Технологічні показники Na-катіонітних фільтрів

\begin{tabular}{|c|c|c|c|}
\hline $\begin{array}{l}№ \\
3 / \Pi \\
\end{array}$ & Показники & $\begin{array}{l}\text { Фільтр I } \\
\text { ступеня }\end{array}$ & $\begin{array}{l}\begin{array}{l}\text { Фільтр II } \\
\text { ступеня }\end{array} \\
\end{array}$ \\
\hline 1 & $\begin{array}{l}\text { Висота шару катіоніту (за заводськи- } \\
\text { ми даними), мм }\end{array}$ & $2,0-2,5$ & 1,5 \\
\hline 2 & Фракція зерен катіоніту & $0,5-1,1$ & $0,5-1,1$ \\
\hline 3 & $\begin{array}{l}\text { Розпушувальна промивка катіоніту, } \\
\text { інтенсивність, л/м²/c, при фракції зе- } \\
\text { рен катіоніту, мм: } \\
0,5-1,1 \\
0,8-1,2\end{array}$ & $\begin{array}{l}4 \\
5\end{array}$ & $\begin{array}{l}4 \\
5\end{array}$ \\
\hline 4 & $\begin{array}{l}\text { Концентрація регенераційного роз- } \\
\text { чину, \% }\end{array}$ & $5-8$ & $8-12$ \\
\hline 5 & $\begin{array}{l}\text { Швидкість проходження регенера- } \\
\text { ційного розчину, м/год }\end{array}$ & $3-4$ & $4-5$ \\
\hline
\end{tabular}

Робота ВПУ котельні підприємства ТзОВ "Гофрон" полягає у досягненні глибшого пом'якшення води завдяки двоступеневій обробці. У цьому випадку у фільтрах I ступеня вода піддається пом'якшенню до залишкової жорсткості $0,1-0,2$ мг-екв/дм ${ }^{3}$. Потім на фільтрах II ступеня жорсткість заздалегідь пом'якшеної води знижується до 0,01 мг-екв/дм ${ }^{3}$. Фільтри II ступеня створюють свого роду бар'єр, що перешкоджає проскакуванню іонів, що видаляються, при випадкових відхиленнях в роботі фільтрів І ступеня. За їх наявності спрощується експлуатація установки, оскільки катіонітові фільтри першого ступеня відключаються на регенера-

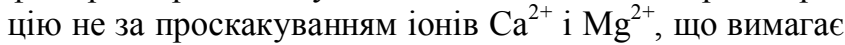
ретельного контролю жорсткості води після цих фільтрів, а за кількістю води, пропущеної через них. 3 огляду на те, що фільтри другого ступеня несуть невелике навантаження на зниження жорсткості води, термін їх роботи до регенерації досягає 150-200 год. Відомо, що при пропуску регенераційного розчину $(\mathrm{NaCl})$ зверху вниз у процесі регенерації повний обмін $\mathrm{Na}^{+}$на $\mathrm{Ca}^{2+}$ i $\mathrm{Mg}^{2+}$, що містяться в катіоніті, відбувається у верхніх шарах завантаження фільтру. При пропусканні розчину $\mathrm{NaCl}$ зверху вниз в ньому зростає концентрація катіонів $\mathrm{Ca}^{2+} \mathrm{i} \mathrm{Mg}^{2+}$, що витісняються 3 катіонітів і знижується концентрація катіонів $\mathrm{Na}^{+}$(DSaNPiN №136/1940-97, 1997).

Після пом'якшення жорсткої води проводять термічну деаерацію води для видалення кисню і вуглекислого газу. Після деаерації очищена вода подається на котел. На основі експлуатаційних даних, виконано розрахунки деяких техніко-економічних показників (табл. 6).

Отже, впровадження ВПУ SF-10A у котельні підприємства ТзОВ "Гофрон" дало змогу:

• отримати високий рівень пом'якшеної води;

- повторно використовувати ВРР, оскільки при цьому зменшується витрата реагенту для регенерації фільтрів першого ступеня на 30-50\%, а також знижуються витрати води на власні потреби;
- економити технічну кухонну сіль на 31 \%. Окрім економії солі, повторне використання ВРР призвело до зниження скидання хлоридів до навколишнього середовища;

- підвищити якість пари, що використовується в турбоустановці для виробництва електроенергіі;

- зменшити витрати на ремонт і обслуговування устатковання в 10 разів;

- значно підвищити рівень автоматизації технологічних процесів і знизити ризик виникнення аварійних ситуацій, пов'язаних з "людським чинником";

- знизити собівартість вироблення $1 \mathrm{~m}^{3}$ води практично в 3 рази.

Табл. 6. Техніко-економічні показники котельні підприємства ТзОВ "Гофрон" після модернізації ВПУ

\begin{tabular}{|c|c|c|}
\hline $\begin{array}{l}\text { № } \\
3 / \Pi\end{array}$ & Назва показника & Значення \\
\hline 1 & Максимальна паропродуктивність, кг/год & 800 \\
\hline 2 & Теплопродуктивність котла, ккал/год & 479880 \\
\hline 3 & $\begin{array}{l}\text { Річний відпуск тепла паровим котлом, } \\
\text { Гкал/рік }\end{array}$ & 2572,2 \\
\hline 4 & Втрата конденсату на виробництві, м $3 /$ год & 0,120 \\
\hline 5 & Річні витрати води на підживлення, м³/рік & 643,2 \\
\hline 6 & \begin{tabular}{|l} 
Річна витрата палива \\
- умовного, тис.т.у.п; \\
- натурального, тис.н.м
\end{tabular} & $\begin{array}{l}295,5 \\
339,8\end{array}$ \\
\hline 7 & $\begin{array}{l}\text { Питома витрата умовного палива на спо- } \\
\text { жите тепло }\left(Q_{H}^{p}=8050 \text { ккал/м }{ }^{3}\right), \text { кг } \\
\text { у.п./Гкал }\end{array}$ & 115 \\
\hline 8 & $\begin{array}{l}\text { ККД котельні підприємства, \% } \\
\text { - до модернізації ВПУ; } \\
\text { - після модернізації ВПУ }\end{array}$ & $\begin{array}{l}82 \\
91\end{array}$ \\
\hline
\end{tabular}

\section{Висновки}

1. Проведено фізико-хімічні дослідження водопровідної води та води після пом'якшувальної ВПУ. Після очищення води іоннообмінним методом жорсткість іiі становила 0,01 мг-экв/л. Встановлено, що інші показники якості води відповідають вимогам.

Встановлено, що використання відпрацьованого розчину 3 концентрацією $\mathrm{NaCl}$ не нижче 3,5\% протягом 30 $50 \%$ часу регенерації не призводить до зменшення тривалості пом'якшення води. Експериментально визначено основні параметри відбору і повторного використання відпрацьованого регенераційного розчину.

2. Вдосконалено ВПУ котельні підприємства ТзОВ "Гофрон" шляхом встановлення установки безперервної дії SF-10A.

3. Проаналізовано ефективність роботи ВПУ SF-10A та розраховано техніко-економічні показники котельні підприємства ТзОВ "Гофрон" після модернізації ВПУ. ККД до модернізації ВПУ підприємства становило $82 \%$, а після модернізації - $91 \%$.

Отже, проведення модернізації ВПУ котельні підприємства ТзОВ "Гофрон" дало змогу збільшити надійність роботи котлів та устатковання, підвищити якість пари, що використовується в турбоустановці для виробництва електроенергії.

\section{Перелік використаних джерел}

Barochkin, E. V., Oparin, M. Iu., Ilichev, A. A., \& Larin, A. B. (2005). Opyt raboty avtomatizirovannoi ustanovki ionoobmennogo umiagcheniia prirodnoi vody. Teploenergetika, 10, 18-23. [In Russian].

DSaNPiN №136/1940-97. (1997). Voda pytna. Hihiienichni vymohy do yakosti vody tsentralizovanoho hospodarsko-pytnoho vodopostachannia. Kyiv: MOZ, 16 p. [In Ukrainian].

Fedoseev, B. S. (2005). Sovremennoe sostoianie vodopodgotovitelnykh ustanovok i vodno-khimicheskikh rezhimov TES. Teploenergetika, 52(7), 2-9. [In Russian]. 
Kucheryk, H. V., Omelchuk, Yu. A., \& Homelia, M. D. (2010). Ionoobminne vyluchennia sulfativ ta khlorydiv z vody. Zbirnyk naukovykh prats SNUYaEtaP, 3(35), 129-136. [In Ukrainian].

Kucheryk, H. V., Omelchuk, Yu. A., \& Homelia, M. D. (2012). Vykorystannia elektrolizu dlia vyluchennia khlorydiv ta sulfativ z luzhnykh reheneratsiinykh rozchyniv. Ecological safety, 1(13), 6873. [In Ukrainian].

Manivasakam, N. (2011). Practical Boiler Water Treatment Handbook. India: Chemical Publishing Company, $557 \mathrm{p}$.

Mysak, Y. S., Tymofieiev, I. L., \& Zaiats, M. F. (2009). Vodopidhotovka, vodno-khimichnyi rezhym ta konservatsiia teploener- hetychnoho ustatkuvannia elektrostantsii. Lviv: NVF "Ukrainski tekhnolohii", 183 p. [In Ukrainian].

RD 10-179-98. (1998). Metodicheskie ukazaniia po razrabotke instruktcii i rezhimnykh kart po ekspluatatcii ustanovok dokotlovoi obrabotki vody $i$ po vedeniiu vodno-khimicheskogo rezhima parovykh $i$ vodogreinykh kotlov. [In Russian].

RD 24.032.01-91. (1991). Metodicheskie ukazaniia. Normy kachestva pitatelnoi vody i para, organizatciia vodno-khimicheskogo rezhima $i$ khimicheskogo kontrolia parovykh statcionarnykh kotlov-utilizatorov i energotekhnologicheskikh kotlov. [In Russian].

Zapolskyi, A. K. (2005). Vodopostachannia, vodovidvedennia ta yakist vody. Kyiv: Higher school, 671 p. [In Ukrainian].

T. P. Kovalenko, S. S. Lys, V. O. Serdiuk, I. R. Galyanchuk, N. M. Lashkovska Lviv Polytechnic National University, Lviv, Ukraine

\section{THE ANALYSIS OF THE EFFICIENCY OF MODERNIZED WATER TREATMENT} EQUIPMENT OF ENTERPRISE BOILER HOUSE

Water treatment is the most significant task in industry while water is an integral part for many manufacturing processes. Initial water contains a lot of different impurities. The application of raw water leads not only to corrosion and limestone deposition in pipes but to premature wear and rising pf power inputs in a thermal network. Therefore, the creation of effective and inexpensive technology for water treatment is a topical problem. This work characterizes, in the broad terms, the situation in water supply. We analysed a scientific and technical literature concerned with the up-to-date technology of water treatment in industry. The object for investigation is the boiler house of Hofron Ltd, situated in Zhovkva district, Malehiv, 70 Lesi Ukrainki str., intended for the steam supply of the enterprise and for heating the industrial premises. The treatment of feed water for Ferroli boilers of Vapoprex HVP 800 type is accomplished by water treatment equipment (WTE) SF-10A. The mentioned installation includes two sodium-cation filters with a common control block and a tank for the preparation of a saline solution. Cation-exchange resin having a high-water hardness capacity is used as a filter medium. In this article we have given reactions which describe the ion-exchange process by two-stage sodium cationating and the advantages of the given method. The laboratory investigations are conducted in order to study the influence of WTE SF-10A upon the quality of water. It is proved that the water hardness decreases to $0.01 \mathrm{mg}$-eqv/1. Several phases for regeneration of the sodium-cation installation are represented. The estimation of the specific $\mathrm{NaCl}(\mathrm{A})$ consumption per a regeneration is given; it is determined that on the first stage filter $\mathrm{A}$ is $135 \mathrm{~g} / \mathrm{g}$-eqv and on the second $-350 \mathrm{~g} / \mathrm{g}$-eqv respectively. The data concerning the effectiveness of WTE SF-10A are analysed and the cost-performance characteristics of Hofron Ltd after WTE modernization are computed. It is determined that the WTE performance factor before and after modernization is equal to 82 and $91 \%$ respectively.

Keywords: water; boiler house; enterprise; water treatment equipment; ion-exchange method; water softening. 